\title{
Adiponectin, total anti-oxidant status, and high sensitivity C-reactive protein in Indonesian men with metabolic syndrome
}

\author{
Cynthia R. Sartika, ${ }^{1,2}$ Widjaja Lukito, ${ }^{3}$ Andi Wijaya ${ }^{1,2}$ \\ ${ }^{1}$ Postgraduate Program in Biomedical Science-Clinical Chemistry, Faculty of Medicine, Hassanuddin University, Makassar, Indonesia \\ ${ }^{2}$ Prodia Clinical Laboratory, Jakarta, Indonesia \\ ${ }^{3}$ SEAMEO-TROPMED Regional Center for Community Nutrition, Faculty of Medicine, University of Indonesia, Jakarta, Indonesia
}

\begin{abstract}
Abstrak
Tujuan Penelitian ini bertujuan untuk menilai penanda biokimia adiponektin, status antioksidan total (SAT), dan high sensitvity C-reactive protein (hsCRP) pada individu dengan dan tanpa sindrom metabolik (SM).

Metode Penelitian pontong lintang pada 36 subyek SM dan 36 subyek tanpa SM yang dilakukan di Jakarta. Indikatorindikator yang diukur adalah adiponektin, SAT dan hSCRP, di samping berat badan, tinggi badan, lingkar pinggang (LP), tekanan darah sistolik, tekanan darah diastolik, dan glukosa darah puasa. Risiko terjadinya SM dihitung dengan odds ratio (OR) adiponektin, hsCRP, dan rasio adiponektin/hsCRP dengan mengambil nilai median sebagai titik dikotomi antara nilai tinggi dan nilai rendah masing-masing parameter tersebut. Hubungan antara adiponektin, SAT, dan hsCRP dengan LP dianalisis dengan uji korelasi Spearman, sedangkan peranan keseluruhan parameter dengan SM dianalisis dengan regresi logistik.

Hasil Adiponektin dan hsCRP berbeda secara signifikan antara subjek dengan dan tanpa $S M(3,1 \pm 1,0 \mathrm{vs} 4,2 \pm 1,4 \mathrm{ug} / \mathrm{mL})$ dan $(3,35 \pm 3,43$ vs 0,97 $\pm 0,92 \mathrm{mg} / \mathrm{L})(p<0,01)$, sedangkan SAT tidak berbeda secara signifikan $(1,28 \pm 0,2 \mathrm{vs} 1,24 \pm 0,1$ $\mathrm{mmol} / \mathrm{L})$. Adiponektin berkorelasi negatif dengan LP ( $r s=-0,436, p<0,01)$, sedangkan SAT dan hsCRP berkorelasi positif dengan LP (masing-masing $r s=0.286, p=0.02$ dan $r s=0,597, p<0.01$ ). Odds ratio (OR) adiponektin dan hsCRP untuk terjadinya SM masing-masing $4(p=0,01)$ dan $\sim 6,8(p<0,01)$, sedangkan risiko pada subyek dengan rasio adiponektin$h s C R P \leq 2.31$ adalah 25 kali lipat $(p<0,01)$ dibanding subyek dengan rasio adiponektin-hsCRP $>2.31$.
\end{abstract}

Kesimpulan Penggunaan rasio adiponektin-hsCRP meningkatkan prediksi SM 4 - 6 kali lipat dibanding bila menggunakan biomarker tunggal. (Med J Indones 2009; 18: 262-8)

\begin{abstract}
Aim To examine biochemical markers of adiponectin, total anti-oxidant status (TAOS) and high sensitvity C-reactive protein $(h s \mathrm{CRP})$ in individuals with and without metabolic syndrome (MetS)

Methods A cross-sectional study on 36 non-MetS and 36 MetS subjects was undertaken in Jakarta. Measured indicators were adiponectin, TAOS and $h s$ CRP, apart from weight, height, waist circumference (WC), systolic blood pressure (SBP), diastolic blood pressure (DBP), and fasting blood glucose (FBG). Odds ratio (OR) of adiponectin, TAOS and $h s C R P$ were calculated to assess risk for the development of MetS. Median values were determined as cutoffs to define high and low values of each parameter. Relationships between adiponectin, TAOS and $h s C R P$ with WC were analyzed by using Spearman correlation analysis, and the contributions of all indicators to the development of MetS were analyzed by using logistic regression.

Results Adiponectin dan $h s \mathrm{CRP}$ differed significantly between non MetS and MetS subjects $(4.2 \pm 1.4$ vs $3.1 \pm 1.0 \mathrm{ug} /$ $\mathrm{mL})$ dan $(0.97 \pm 0.92 v s 3.35 \pm 3.43 \mathrm{mg} / \mathrm{L})(p<0.01)$, but no significant difference was found in TAOS $(1.24 \pm 0.1 v s 1.28$ $\pm 0.2 \mathrm{mmol} / \mathrm{L})$. Adiponectin associated negatively with $\mathrm{WC}\left(\mathrm{r}_{\mathrm{s}}=-0.436 ; p<0.01\right)$, while TAOS and $h s \mathrm{CRP}$ associated positively with WC $(\mathrm{r}=0.286, \mathrm{p}=0.02$ and $\mathrm{r}=0.597, p<0.01)$. The odds ratios (ORs) of adiponectin and $h s \mathrm{CRP}$ for the development of MetS were $4(p=0.01)$ and $\sim 6,8(p<0.01)$, respectively; while the risk of subjects with adiponectin$h s \mathrm{CRP}$ ratio of $\leq 2.31$ to develop MetS was 25 times $(p<0.01)$ those with adiponectin- $h s \mathrm{CRP}$ ratio $>2.31$.
\end{abstract}

Conclusion The use of adiponectin- $h s \mathrm{CRP}$ ratio increases the predictive power for the occurrence of MetS by $4-6$ times the predictive power of adiponectin or $h s \mathrm{CRP}$ alone. (Med J Indones 2009; 18: 262-8)

Key words: adiponectin, hsCRP, total anti-oxidant status, metabolic syndrome. 
Metabolic syndrome (MetS) is clinically defined as collective cardio-vascular disease (CVD) risks that include central obesity, dyslipidemia, hyperglycemia and hypertension. This syndrome is well documented to contribute to the development of CVD, type 2 diabetes and other related degenerative diseases like non-alcoholic steato-hepatitis (NASH), polycystic ovary syndrome (PCOS), and cancer. MetS is a growing health problem in developed and developing countries, including Indonesia. Data from the Indonesian Society for the Study of Obesity (ISSO) showed that the prevalence of MetS, using the criteria recommended by the National Cholesterol Education Program (NCEP)-Adult Treatment Program (ATP) III, was $\approx 24 \%$ of 3429 adult people studied. ${ }^{1-5}$

Central obesity is a major component of MetS events, but the underlying mechanism of metabolic problems in MetS is not fully understood. Apart from being as a fat storage, adipose tissue has been considered as an organ that produces active biological molecules (adipokine), proinflammatory cytokines, anti-inflammatory hormones and other biological substances. It is evidence that obesity contributes to increased expression of proinflammatory cytokines in the blood circulation, which then leads to inflammation of the vascular wall. . $, 3,5,6^{-}$

Furthermore, obesity is strongly associated with increased lipid metabolism. In individuals with MetS, production of reactive oxygen species (ROS) is elevated in both circulation and adipocytes. Increased production of ROS in adipocytes contributes to the interruption of the oxidation-reduction (redox) reaction, which, in turn, leads to the decline of anti-oxidative enzymes in the blood circulation. This condition is known as oxidative stress, which plays important roles in the pathogenesis of many degenerative diseases. High oxidative stress leads to disorder of metabolism in adipose tissue, which constitutes an early pathway to MetS, hypertension and coronary atherosclerosis. ${ }^{1}$

There is also compelling evidence that in individuals with MetS, the occurrence of endothelial dysfunction and intima media thickening of the vascular wall was consistent with elevated levels of C-reactive protein (CRP) and adhesion molecules in plasma. CRP production is induced by interleukin-6 (IL-6) and regulated by tumor necrosis factor (TNF- $\alpha$ ). CRP has the potential to recruit low-density lipoprotein (LDL) through the induction of cytokines to express proinflammatory process. High levels of CRP and adhesion molecules contribute to endothelial dysfunction and intima-media thickening of the vascular wall. ${ }^{6-8}$
The abovementioned underlying background has provided inspiration to further explore the patho-biologic mechanism of inflammation, and its interplays with oxidative stress and endothelial dysfunction in individuals with MetS, especially those with central obesity, in line with the common soil hypothesis. Furthermore, available studies on the links between inflammation, oxidative stress and endothelial dysfunction (vascular disease triads) $)^{9}$ in Indonesian individuals are very limited, albeit coinciding with the prevailing MetS in Indonesia. ${ }^{2}$ These conditions justified the need to undertake the current study. In this study, biochemical parameters with significant correlation for determining risks of MetS prior to the development of vascular diseases were used.

\section{METHODS}

\section{Study Design}

The design of this study was case control, comparing adiponectin, $h s \mathrm{CRP}$, TAOS, and various metabolic profiles between normal (non-MetS) subjects as control and subjects with MetS as case. Data collection was commenced in October 2005 and completed in March 2006. The study proposal was approved by the Health Research Ethics Committee of the Faculty of Medicine, University of Hasanuddin.

\section{Subjects}

Subjects were recruited from Prodia Clinical Laboratory in Jakarta for general medical check-up, employees and relatives of Prodia Clinical Laboratory in Jakarta. Subjects who were apparently healthy, male, aged 4060 years old and willing to follow the study protocol, were considered eligible to be included in the study.

Subjects who were consuming steroids; or had consumed antioxidant supplements such as vitamins $\mathrm{C}$ and or $\mathrm{E}$, green tea or other supplements known as antioxidants for the last 3 weeks; or had been treated with anti-inflammatory drugs such as statins or tiazolidinedione for the last 3 weeks; or had liver dysfunction, kidney dysfunction, asthma, fever, were excluded from the study.

Sample size calculation was based on the difference in the value of serum $h s \mathrm{CRP}$ and adiponectin concentrations between non-MetS and MetS subjects. The power and level of significance were defined at $80 \%$ and $5 \%$, respectively. Based on the study by Xydakis et al, ${ }^{10} 16$ 
subjects in each group were required to detect $2 \mathrm{mg} / \mathrm{L}$ difference in serum $h s \mathrm{CRP}$ concentration. In a similar way, 25 subjects in each group were required to detect $3 \mathrm{ng} / \mathrm{mL}$ difference in serum adiponectin concentration. Therefore, a total of 72 subjects, consisting of 36 nonMetS and 36 MetS subjects, were considered adequate in the present study.

Subjects in the MetS category met the International Diabetes Federation (IDF) criteria for MetS, ${ }^{11}$ they were central obesity [waist circumference (WC) $\geq$ $90 \mathrm{~cm}$ ] with two of the other four clinical indicators: triglycerides $\geq 150 \mathrm{mg} / \mathrm{dL}$, HDL-C $<40 \mathrm{mg} / \mathrm{dL}$, systolic blood pressure (SBP) $\geq 130$ or diastolic blood pressure (DBP) $\geq 85 \mathrm{~mm} \mathrm{Hg}$, fasting blood glucose (FBG) $\geq 100$ $\mathrm{mg} / \mathrm{dL}$. Each subject was provided with explanation about the study, and signed informed consent prior to the commencement of the study.

\section{Anthropometric Measurement}

Bodyweight(BW) wasmeasuredinkilograms tothenearest $0.1 \mathrm{~kg}$, with light clothes on, using a beam scale Tanita (Tanita, Japan). Height $(\mathrm{Ht})$ was measured in centimeters to the nearest $0.1 \mathrm{~cm}$, in standing position with socks and shoes removed, using a microtois (stature meter). Waist circumference was measured in centimeters to the nearest $0.1 \mathrm{~cm}$, using a flexible non-elastic tape made by Roche (Roche, Switzerland). Waist circumference was measured at the midway region between the lowest rib margin and the iliac crest, in standing position with abdomen relaxed, feet together and weight equally divided over both legs. Body mass index (BMI) was calculated by dividing body weight in $\mathrm{kg}$ by height in squared meter.

\section{Blood Pressure Measurement}

Blood pressure was measured using a sphygmomanometer during the course of the study. Subjects were seated for at least $5 \mathrm{~min}$ before the actual measurement was taken. The first Korotkoff sound represented systolic blood pressure and the fifth Korotkoff sound (when sound just disappears) was taken as the diastolic blood pressure. Two measurements were taken with a 5 min interval, and the average value was used.

\section{Biochemical Assessment}

Fasting blood samples were collected in the morning between 07:00 to 10:00 am. Plasma and serum were separated immediately by centrifugation and aliquots were frozen at $-20^{\circ} \mathrm{C}$ for subsequent batched analysis for adiponectin and high-sensitivity C-reactive protein (hsCRP). Total anti-oxidant status (TAOS) and biochemical laboratory test were determined immediately soon after the separation process.

Serum TAOS, triglycerides, total cholesterol (TC), low and high-density lipoprotein cholesterol (LDL-C and HDL -C), FBG, creatinine, alanine amino transferase (ALT) and aspartate amino transferase (AST) levels were assayed by the Prodia Clinical Laboratory's routine chemistry procedures. Serum AST, ALT and creatinine were determined using the International Federation of Clinical Chemistry (IFCC) method and reagents manufactured by Roche (Mannheim, Germany). The Standard automated glucose oxidase method was used to determined glucose, reagents manufactured by Roche (Mannheim, Germany). Homogeneous method was used to determine HDL-C, using reagents manufactured by Daiichi ${ }^{\circledR}$ Tokyo-Japan. The phosphate glycerol oxidaseperoxidase anti-peroxidase (GPO-PAP) method was used to determine triglycerides, using reagent manufactured by Roche (Mannheim, Germany).

Fasting plasma adiponectin was measured using a commercially available enzyme-linked immunoassay (ELISA) kit (Daichii ${ }^{\circledR}$, Tokyo-Japan). TAOS was determined in one run using colorimetric methods, reagents produced by RANDOX ${ }^{\circledR}$ (Crumlin, UK). The concentration of CRP was determined using a highsensitivity chemiluminescent assay on the Immulite $^{\circledR}$ (Dade-Behring, Los Angeles, CA, USA).

\section{Data Analysis}

Data analysis was done using SPSS 13.0 statistical analysis software for Windows (SPSS Inc., Chicago, IL, USA). Distributions of continuous variables were assessed for normality using the Kolmogorov-Smirnov. For continuous variables with normal distributions, such as anthropometric and biochemical measures, data were presented as mean \pm SD. Statistical analysis was performed using a two-tailed $t$ test for comparison between two groups.

Associations between continuous variables with approximately normal distributions were described using Spearman's correlation coefficients. All tests were twosided and considered significant at $p<0.05$.

Logistic regression analysis was used to assess OR for the development of MetS. For this purpose, median values of adiponectin, TAOS and $h s \mathrm{CRP}$ were dichotomized to assume risk for the development of MetS. 


\section{RESULTS}

Table 1 showed that both non-MetS and MetS subjects had comparable age, smoking habit, height, serum LDL-C and TAOS concentrations. The MetS subjects had higher body weight, BMI, WC, SBP, DBP, triglycerides, and $h s \mathrm{CRP}$ than the non-MetS subjects. On the other hand, the MetS subjects had lower HDL-C and adiponectin than their non-MetS counterpats.

Figures 1 demonstrate the association between WC and adiponectin, TAOS, and $h s \mathrm{CRP}$. WC associated negatively with adiponectin concentrations $\left(\mathrm{r}_{s}=-0.418\right.$; $p<0.01)$, but associated positively with TAOS $\left(\mathrm{r}_{s}=\right.$ $0.286 ; p=0.015)$ and $h s \mathrm{CRP}\left(\mathrm{r}_{s}=0.597 ; p<0.01\right)$.

Median values of serum adiponectin, TAOS and $h s$ CRP concentrations were used as cut-offs to define risk for the development of MetS. Subjects with serum adiponectin concentrations $<3.47 \mu \mathrm{g} / \mathrm{dL}$, serum $h s \mathrm{CRP}$ concentrations $>1.44 \mathrm{mg} / \mathrm{L}$ and adiponectin- $h s \mathrm{CRP}$ ratio $\leq 2.31$ were considered at risk for MetS. These variables were then included in the logistic regression model.

Table 2 presents the OR for the development of MetS. It is apparent that the risk of subjects with adiponectin concentrations $<3.47 \mu \mathrm{g} / \mathrm{dL}$ to develop MetS was 4 times those with adiponectin concentrations $\geq 3.47 \mu \mathrm{g} /$ $\mathrm{dL}$. The risk of subjects with $h s \mathrm{CRP}$ concentrations $>$ $1.44 \mathrm{mg} / \mathrm{L}$ to develop MetS was $\sim 6.8$ times those with $h s \mathrm{CRP}$ concentrations $\leq 1.44 \mathrm{mg} / \mathrm{L}$. Moreover, the risk of subjects with adiponectin- $h s \mathrm{CRP}$ ratio $\leq 2.31$ was 25 times those with adiponectin- $h s \mathrm{CRP}$ ratio $>2.31$.

Table 1. Basic clinical, anthropometric and biochemical characteristics of non-MetS and MetS subjects.

\begin{tabular}{lccc}
\hline Variable & Non MetS & MetS & $\mathrm{p}$ \\
$\mathrm{N}$ & 36 & 36 & $\mathrm{NS}$ \\
\hline Age $($ year $)$ & $47.6 \pm 5.6$ & $48.1 \pm 5.6$ & $\mathrm{NS}$ \\
Smoking habit & $7(19.4 \%)$ & $7(19.4 \%)$ & \\
Anthropometric and clinical variables & & & \\
$\quad$ Height $(\mathrm{cm})$ & $166.2 \pm 6.4$ & $166.8 \pm 6.2$ & $\mathrm{NS}$ \\
Weight $(\mathrm{kg})$ & $61.6 \pm 5.9$ & $80.2 \pm 9.9$ & $<0.01$ \\
BMI $\left(\mathrm{kg} / \mathrm{m}^{2}\right)$ & $22.3 \pm 2.2$ & $28.9 \pm 3,9$ & $<0.01$ \\
WC $(\mathrm{cm})$ & $81,0 \pm 6.2$ & $98.6 \pm 6.8$ & $<0.01$ \\
SBP $(\mathrm{mm} \mathrm{Hg})$ & $110(90,130)$ & $127.5(90,200)$ & $<0.01$ \\
DBP $(\mathrm{mm} \mathrm{Hg})$ & $72.5(69,99)$ & $80(70,132)$ & $<0.01$ \\
Biochemical variables & & & \\
$\quad$ HDL-C $(\mathrm{mg} / \mathrm{dL})$ & $48.0 \pm 6.8$ & $36.4 \pm 5.6$ & $<0.01$ \\
Triglycerides $(\mathrm{mg} / \mathrm{dL})$ & $101.9 \pm 28.8$ & $288.5 \pm 159.3$ & $<0.01$ \\
LDL-C $(\mathrm{mg} / \mathrm{dL})$ & $141.4 \pm 30.7$ & $125.6 \pm 38.0$ & $\mathrm{NS}$ \\
Adiponectin $(\mu \mathrm{g} / \mathrm{mL})$ & $4.2 \pm 1.4$ & $3.1 \pm 1.0$ & $<0.01$ \\
TAOS $(\mathrm{mmol} / \mathrm{L})$ & $1.24 \pm 0.1$ & $1.28 \pm 0.2$ & $\mathrm{NS}$ \\
hsCRP $(\mathrm{mg} / \mathrm{L})$ & $0.97 \pm 0.92$ & $3.35 \pm 3.43$ & $<0.01$ \\
\hline
\end{tabular}

Description: $\mathrm{MetS}=$ Metabolic syndrome; $\mathrm{DBP}=$ diastolic blood pressure; $\mathrm{SBP}=$ systolic blood pressure; $\mathrm{BMI}=$ body mass index; HDL-C = high-density lipoprotein-cholesterol; LDL-C= low-density lipoprotein-cholesterol; FBG= fasting blood glucose; TAOS= total antioxidant status; hsCRP= high sensitivity $\mathrm{C}$-reactive protein. 
Table 2. Logistic regression analysis with the presence or absence of MetS as dependent variables, and adiponectin, hsCRP and TAOS as independent variables

\begin{tabular}{lcrrr}
\hline & \multirow{2}{*}{ Variable } & \multirow{2}{*}{ OR } & $\mathrm{p}$ & \multicolumn{2}{c}{$95 \%$ C.I } \\
\cline { 5 - 6 } & & \multicolumn{1}{c}{ Unper } \\
\hline Adiponectin & 4.00 & 0.01 & 1.501 & 10.685 \\
TAOS & 0.46 & 0.10 & 0.177 & 1.166 \\
hsCRP & 6.76 & $<0.01$ & 2.410 & 18.962 \\
Adiponektin-hsCRP ratio & 25.0 & $<0.01$ & 7.24 & 86.36 \\
\hline
\end{tabular}

Description: $\mathrm{TAOS}=$ total anti-oxidant status; hsCRP $=$ high sensitivity $\mathrm{C}$-reactive protein; $\mathrm{CI}=\mathrm{Confidence}$ interval

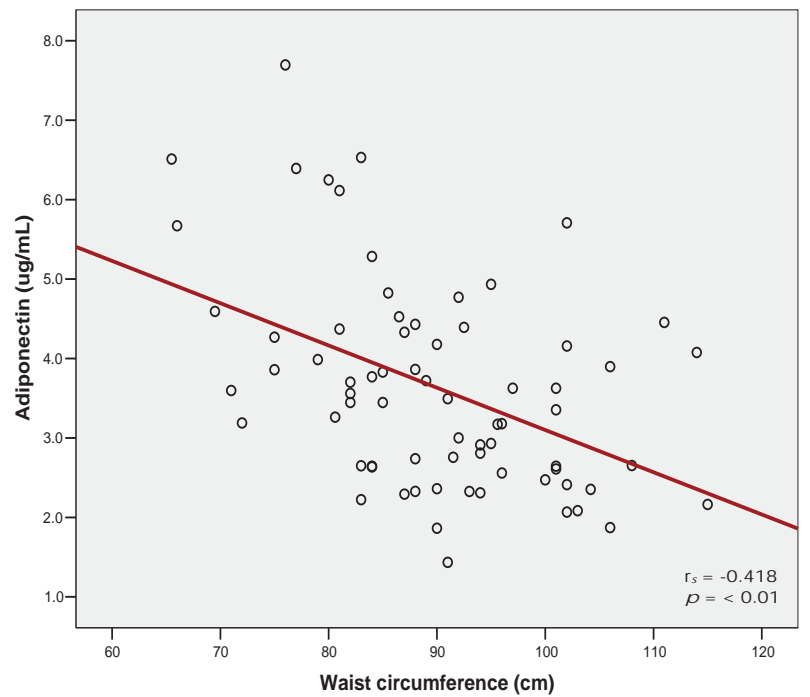

Figure 1. The relations between waist circumference and adiponectin concentrations

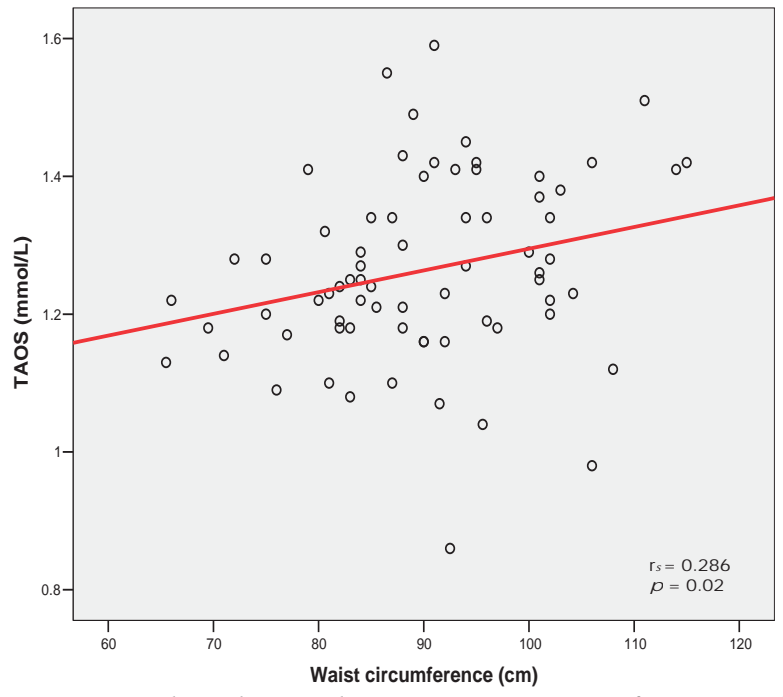

Figure 2. The relations between waist circumference and TAOS concentrations.

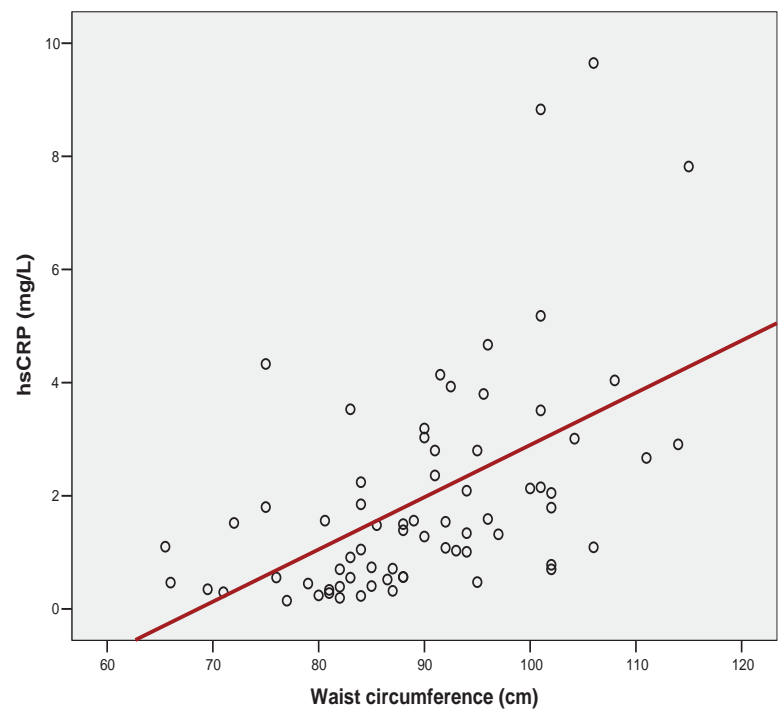

Figure 3. The relations between waist circumference and hsCRP concentrations 


\section{DISCUSSION}

This study was designed to verify the notion that low grade inflammation was linked to the development of CVD through MetS, which has been described extensively in the western literatures. IDF has put forward central obesity as the key clinical indicator of MetS. ${ }^{11}$ This model is assumed to contribute to the low levels of adiponectin, as an anti-inflammatory adipokine in MetS, ${ }^{8}$ and our findings have confirmed this notion.

The current study was one, amongst others, describing characteristics of non-MetS and MetS Indonesian men. Studies on MetS using Indonesian ethnic are hardly available. Male subjects were chosen to minimize the variations due to differences in endocrinologic profiles. Moreover, we applied IDF criteria to define the MetS and challenged the hypothesis that this criteria was comparable, if not better than NCEP-ATP III's or AHA's clinical definitions for MetS, as mostly described in many studies. ${ }^{12,13}$

In comparison with the studies done by Devaraj et al ${ }^{12}$ and Mojiminiyi et al. ${ }^{13}$ using different subjects' entry criteria, the IDF criteria demonstrated its validity for the manifestation of adiponectin and $h s \mathrm{CRP}$ concentrations in non-MetS and MetS subjects. However, the ORs of adiponectin, $h s \mathrm{CRP}$, and adiponectin- $h s \mathrm{CRP}$ ratio for the development of MetS in Devaraj's study ${ }^{12}$ were much lower than those of our study. These findings indicate that the IDF criteria are more relevant to be applied whenever adiponectin and $h s \mathrm{CRP}$ are used to predict the occurrence of MetS. IDF criteria affirmed the inclusion of central obesity as the key clinical indicator to enter the definition of MetS. Central obesity is indeed a key determinant of hypoadiponectinemia and low grade inflammation, as has been shown in our study. Ouchi et $\mathrm{al}^{8}$ were able to show reciprocal association of CRP and adiponectin in blood stream and adipose tissue.

In contrast to the study of Furukawa et al. ${ }^{1}$, which demonstrated differences in the levels of superoxide dismutase (SOD), glutathione peroxidase (GPX), catalase, peroxidase and lipid F2-Isoprostan (F2IsoPs) between non-MetS and MetS subjects, this study was not able to show differences in the levels of TAOS between the non-MetS and MetS subjects. There are at least 2 arguments to explain this finding. Firstly, the measured antioxidants were less specific. The measurement of TAOS was based on the capacity of biological fluids to inhibit the production of thio- barbituric acid reactive substance (TBARS) from sodium benzoate which is influenced by the free radicals generated by Fenton reaction of the reagent used. ${ }^{14,15}$ Furthermore, within the serum specimens, there are constituents of uric acid, pyruvate and albumin, which can increase the capacity of TAOS. Arginine, cysteine, tryptophan and reduced glutathione (GSH) are also considered as weak antioxidants. ${ }^{15,16}$ Those serum constituents were not measured in the current study. Secondly, the TAOS variable has significant limitations that it is a measure of serum antioxidant and may not reflect the state of intracellular antioxidants, or targeted areas of stress, such as oxidative stress on endothelial cells or vascular smooth muscle cells as the target of atherogenesis process. ${ }^{17}$

Verma et al. ${ }^{7}$ suggested a notion that CRP was a circulating biomarker of endothelial dysfunction. This notion was based on the fact that human recombinant $\mathrm{CRP}$, at the concentrations known to predict vascular disease, elicited a multitude of effects on endothelial biology favoring a pro-inflammatory and proatherosclerotic phenotype. ${ }^{7,18}$ Findings of this study indicated the high OR value for subjects with serum $h s \mathrm{CRP}$ concentrations of higher than median to develop MetS. This specific finding has led to a speculation that subjects with MetS who participated in this study had developed endothelial dysfunction.

In conclusions, the use of adiponectin-hsCRP ratio increases the predictive power for the occurrence of MetS by 4-6 times the predictive power of adiponectin or $h s \mathrm{CRP}$ alone. Our study was able to demonstrate that in Indonesian men, IDF criteria is recommended to be applied adiponectin and $h s \mathrm{CRP}$ are used to predict the occurrence of MetS.

\section{Acknowledgements}

This study was fully funded by the Prodia Foundation for Research and Training. We are indebted to the technical staff of the Prodia Clinical Laboratory, Clinical Trial and Research and Development Departments for their valuable assistance in undertaking specimen collection in the field and biochemical assessments.

\section{REFERENCES}

1. Furukawa S, Fujita T, Shimabukuro M. Increased oxidative stress in obesity and its impact on metabolic syndrome. J Clin Invest 2004;114:1752-61.

2. Semadji, G. The prevalence of the metabolic syndrome: Findings from the epidemiological study on obesity and its 
co-morbidities in Indonesian population. The $3^{\text {rd }}$ National Obesity Symposium. Jakarta: Indonesian Society for the Study on Obesity, 2004.

3. Grundy S. Metabolic syndrome scientific statement by the American Heart Association and the National Heart, Lung, and Blood Institute. Arterioscler Thromb Vasc Biol 2005;25:2243-4.

4. Stern PM, Williams K, Gonzales-Villalpando C, Hunt JK, Haffner SM. Does the metabolic syndrome improve identification of individuals at risk of type 2 diabetes and/or cardiovascular disease? Diab Care 2004;27:2676-81.

5. Sonnenberg GE, Krakower GR, Kissebah AH. A novel pathway to the manifestations of metabolic syndrome. Obes Res 2004;12:180-6.

6. Reilly MP, Rader DJ. The Metabolic syndrome: more than the sum of its part? Circulation 2003;108:1546-51.

7. Verma S, Buchanan MR, Anderson T. Endothelial function testing as a biomarker of vascular disease. Circulation 2003;108:2054-9.

8. Ouchi N, Kihara S, Funahashi T, Matsuzawa Y. Walsh $\mathrm{K}$. Reciprocal association of $\mathrm{C}$-reactive protein with adiponectin in blood stream and adipose tissue. Circulation 2003;107:671-4.

9. Ceriello A, Motz E. Is oxidative stress the pathogenic mechanism underlying insulin resistance, diabetes, and cardiovascular disease? The common soil hypothesis revisited. Arterioscler Thromb Vasc Biol 2004;24:816-23.

10. Xydakis, AM., Case, CC., Jones, PH., Hoogeveen, RC., Liu, M-Y., Smith, EO., Nelson, KW. and Ballantyne, CM. Adiponectin, inflammation, and the expression of the metabolic syndrome in obese individuals: The impact of rapid weight loss through caloric restriction. J Clin Endocrinol Metab 2004;89:2697-703.

11. Alberti KG, Zimmet P, Shaw J. IDF epidemiology task force consensus group: The metabolic syndrome: a new worldwide definition. Lancet 2005;366:1059-62.

12. Mojiminiyi OA, Abdella NA, Al Arouj M, Nakhi AB. Adiponectin, insulin resistance and clinical expression of the metabolic syndrome in patients with type 2 diabetes. Int J Obes 2007;31:213-20

13. Devaraj S, Swarbrick MM, Singh U, Adams-Huet B, Havel PJ, Jialal I. CRP and adiponectin and its oligomers in the metabolic syndrome: Evaluation of new laboratory-based biomarkers. Am J Clin Pathol 2008;129:815-22.

14. Cao G, Prior RL. Comparison of different analytical methods for assessing total antioxidant capacity of human serum. Clin Chem 1998;44:1309-15.

15. Koracevic D, Koracevic G, Djordjevic V, Andredjevic S, Cosic V. Method for measurement of antioxidant activity in human fluids. J Clin Pathol 2001;54:356-61.

16. Psotová J, Zahálková J, Hrbáč J, Šimánek V, Bartek J. Determination of total antioxidant capacity in plasma by cyclic voltammetry. two case reports. Biomed Papers 2001;145:81-3.

17. Wang CC, Chu CY, Chu KO, Choy KW, Khaw KS, Rogers $\mathrm{MS}$, et al. Trolox-equivalent antioxidant capacity assay versus oxygen radical absorbance capacity assay in plasma. Clin Chem 2004;50:952-4.

18. Szmitko PE, Wang C-H, Weisel RD, Almeida JR, Anderson TJ, Verma S. New marker of inflammation and endothelial cell activation: Part I. Circulation 2003;108:1917-23. 